\title{
MENINGKATKAN KINERJA KEUANGAN RETURN ON EQUITY \\ (ROE) MELALUI RASIO STRUKTUR MODAL DEBT TO ASSET RATIO \\ (DAR) DAN DEBT TO EQUITY RATIO (DER) PADA PT BANK \\ MANDIRI TBK YANG TERDAFTAR DI BURSA EFEK INDONESIA
}

\author{
Armalinda \\ Sekolah Tinggi Ilmu Ekonomi Serelo Lahat \\ Email : armalinda.stie@gmail.com
}

\begin{abstract}
This study aims to determine how much influence the Debt to Assets Ratio (DAR) and Debt to Equity Ratio (DER) have on the Return on Equity (ROE) of PT Bank Mandiri Tbk which are listed on the Indonesia Stock Exchange. The research design used in this research is associative / quantitative research. The population in this study is the annual financial statements of PT. Bank Mandiri Tbk for the period 2012-2019, while the sample was taken using time series data, namely the annual financial statements of PT. Bank Mandiri Tbk for the period 2012-2019 which consists of balance statements, income statements, and cash flow from funding activities from 2012 to 2019. The result of the coefficient of determination ( $R$ Square) is 0.813 . This figure means that 0.813 or $81.3 \%$ of the diversity of data from financial performance data can be explained by the two independent variables, namely the Debt to Asset Ratio and the Debt to Equity Ratio. While the rest $(1-0.813=0.817)$ or $18.7 \%$ is explained by other factors outside the study. The results of statistical tests show that the Asset Ratio and Debt to Equity Ratio together (simultaneously) have an effect on financial performance (Return on Equity).
\end{abstract}

Keyword: Debt to Assets Ratio, Debt to Equity Ratio, Return on Equity

\section{PENDAHULUAN}

Pemilihan pemenuhan kebutuhan dana perusahaan cenderung dihadapkan pada keputusan dalam menggunakan teknik pengukuran modal, baik yang berasal dari dalam maupun luar. Pembuatan analisis laporan keuangan menjadi salah satu bentuk bukti kinerja yang harus dipenuhi bagi pengelola. Bagi pengurus dan pengelola, laporan keuangan berfungsi sebagai salah satu dasar pertimbangan dalam menyusun rencana dan pengambilan keputusan terutama dalam bidang keuangan. Unsur yang harus diperhatikan dalam mengelola fungsi keuangan adalah seberapa besar pengeluaran yang harus diperhitungkan dalam 
penggunaan keuangan sebagai bentuk bukti pemakaian dana dan jangka waktu dana tersebut bisa dipergunakan. Tingkat efektivitas manajemen bisa diukur melalui rasio profitabilitas yang dimiliki. Profitabilitas merupakan rasio dalam penilaian kemampuan perusahaan guna mencari keuntungan. Dengan kata lain penggunaan rasio profitabilitas untuk menunjukan efisiensi perusahaan. Dalam penelitian ini diukur melalui ROE, pengukuran ini merupakan langkah awal yang harus dilakukan bagi calon investor mengukur tingkat besarnya perusahaan dalam menggunakan uang untuk memperoleh keuntungan yang dapat dimanfaatkan sebagai modal pengembangan suatu perusahaan.

Pembiayaan kegiatan perusahaan menggunakan sumber dana yang permanen (jangka panjang) didapat dari uang yang belum dibayarkan pada kurun waktu yang relatif lama beserta uang sendiri, kedua unsur tersebut yang akan membentuk struktur modal. Irham Fahmi (2017) menyatakan bahwa : "Suatu bentuk dari besarnya finansial perusahaan antara pembiayaan dalam kurun waktu yang relatif lama beserta pembiayaan pada suatu perusahaan yang merupakan bentuk dari struktur modal”. Untuk mengetahui laba perusahaan, alat analisis yang digunakan sebagai dasar analisis kinerja keuangan perusahaan adalah teknik rasio keuangan. Analisis rasio keuangan menurut Irham Fahmy (2017) merupakan alat pengukuran dalam perbandingan jumlah dari satu jumlah dengan jumlah lainnya.

Tabel 1.1

Tabel perhitungan kinerja keuangan

PT Bank Mandiri tahun 2012-2019

\begin{tabular}{|c|c|c|c|}
\hline Tahun & DAR (X1) & DER (X2) & ROE (Y) \\
\hline 2012 & 90,64 & 98,14 & 22,18 \\
\hline 2013 & 81,78 & 72,04 & 20,26 \\
\hline 2014 & 81,6 & 67,77 & 20,96 \\
\hline 2015 & 81,39 & 67,2 & 21,2 \\
\hline 2016 & 81,51 & 66,48 & 19,7 \\
\hline 2017 & 80,89 & 61,61 & 17,7 \\
\hline 2018 & 79,38 & 53,76 & 9,55 \\
\hline 2019 & 78,95 & 52,23 & 12,61 \\
\hline
\end{tabular}

Sumber: data diolah, 2021 
Berdasarkan perhitungan tabel diatas dengan laporan keuangan terlihat bahwa pada variabel dependent di tiap tahunnya mengalami fluktuasi yaitu di tahun 2012 sebesar 22,18 mengalami penurunan 20,96 ditahun 2014 selanjutnya mengalami kenaikan di tahun 2015 menjadi 21,2, lalu menurun di angka 19,7 di tahun 2016, kemudian terus terjadi penurunan hingga tahun 2018 kemudian meningkat lagi menjadi 12,61 di tahun 2019. Dari permasalahan diatas, maka peneliti mengambil judul : "Meningkatkan Kinerja Keuangan Return on Equity (ROE) Melalui Rasio Struktur Modal Debt to Asset Ratio (DAR) dan Debt to Equity Ratio (DER) Pada PT Bank Mandiri Tbk yang terdaftar di Bursa Efek Indonesia Periode 2012-2019”.

\section{Penelitian Terdahulu}

Sebagai bahan acuan dalam penulisan, peneliti menggunakan penelitian terdahulu.

Tabel 2.

Penelitian Terdahulu

\begin{tabular}{|c|c|c|c|c|c|c|c|}
\hline No & $\begin{array}{l}\text { Nama } \\
\text { Penelitian/ } \\
\text { Tahun }\end{array}$ & Judul & Tujuan & $\begin{array}{c}\text { Metode } \\
\text { Penelitian }\end{array}$ & Hasil Penelitian & Persamaan & Perbedaan \\
\hline 1 & $\begin{array}{c}\text { Intan Sari } \\
(2018)\end{array}$ & $\begin{array}{c}\text { Pengaruh } \\
\text { Debt To } \\
\text { Equity Ratio } \\
\text { dan Current } \\
\text { Ratio } \\
\text { Terhadap } \\
\text { Return On } \\
\text { Equity. Studi } \\
\text { empiris pada } \\
\text { perusahaan } \\
\text { sub sektor } \\
\text { kabel yang } \\
\text { terdaftar di } \\
\text { BEI } 2017\end{array}$ & $\begin{array}{c}\text { Untuk } \\
\text { mengetahui } \\
\text { pengaruh dan } \\
\text { menganalisis } \\
\text { Debt To } \\
\text { Equity Ratio } \\
\text { dan Current } \\
\text { Ratio } \\
\text { Terhadap } \\
\text { Return On } \\
\text { Equity }\end{array}$ & $\begin{array}{l}\text { Deskriptif } \\
\text { Kuantitatif }\end{array}$ & $\begin{array}{c}\text { Hasil analisis } \\
\text { secara simultan } \\
\text { rasio } D E R \text { dan } C R \\
\text { secara bersama- } \\
\text { sama } \\
\text { tidak berpengaruh } \\
\text { signifikan } \\
\text { terhadap } R O E \\
\text { perusahaan sub } \\
\text { sektor kabel }\end{array}$ & $\begin{array}{c}\text { Menggunakan } \\
\text { Debt To } \\
\text { Equity Ratio }\end{array}$ & $\begin{array}{c}\text { Objek } \\
\text { penelitian }\end{array}$ \\
\hline
\end{tabular}

\section{KAJIAN PUSTAKA DAN PENGEMBANGAN HIPOTESIS}

\section{Kinerja Keuangan}

Kinerja keuangan perusahaan merupakan alat analisis dalam menganalisa keuangan perusahaan secara tepat dengan menerapkan aturan-aturan yang telah ditetapkan (Fahmi, 2011). Kinerja keuangan menurut Munawir (2010) dilakukan 
untuk menganalisis rasio keuangan suatu perusahaan guna mengetahui kondisi keuangan. $R O E$ disebut juga laba atas equity digunakan dalam proses penilaian kinerja keuangan. Dibeberapa sumber lain menyatakan hal ini dengan sebutan perputaran total asset, yang digunakan suatu perusahaan untuk menilai seberapa besar hasil yang didapat untuk memperoleh keuntungan dengan memanfaatkan sumber daya yang ada.

$$
\text { ROE }=\frac{\text { Laba Bersih }}{\text { Ikuizas }} \times 100 \%
$$

\section{Struktur Modal}

Definisi dari struktur modal merupakan suatu perbandingan antara modal asing dengan modal sendiri. Modal asing merupakan pembayaran yang belum dilakukan dalam kurun waktu cepat maupun lama. Menurut Sudana (2017) modal sendiri dibagi menjadi dua yaitu : keuntungan yang belum diberikan dan penyertaan perusahaan yang dimiliki. Struktur modal didefinisikan sebagai ukuran besarnya aset suatu perusahaan yang diukur dari pembiayaan dalam kurun waktu yang lama dan sumber uang sendiri (Irham Fahmi, 2017). Struktur modal dibagi menjadi dua komponen yaitu uang kepemilikan sendiri dan uang kepemilikan dari luar (Bambang, 2011). Kepemilikan sendiri merupakan sekumpulan uang atau jasa sebagai aset suatu perusahaan yang tidak ditentukan batas waktu, terdiri dari keuntungan modal dan keuntungan yang ditahan. Sedangkan Modal Asing harus dibayarkan (dalam bentuk uang) dari seorang pemilik kepada pihak yang meminjamkan, digunakan untuk perluasan perusahaan yang terdiri dari pinjaman obligasi dan pinjaman hipotik.

\section{Rasio Struktur Modal}

Suatu perusahaan dapat terlihat adanya suatu bentuk kenaikan dan penurunan keuangan, hal ini diperlukannya alat dalam menganalisis data keuangan yang tercermin didalam laporan keuangan. Penelitian ini menggunakan rasio struktur modal $D A R$ dan DER. Sjahrial dan Purba (2013) menyatakan bahwa rasio struktur modal terbagi menjadi dua bagian yaitu : 
1. Debt to Assets Ratio (DAR)

Rasio $D A R$ diperlukan dalam penelitian ini dalam mengukur besar kecilnya perusahaan mendapatkan suatu keuntungan dengan menjumlahkan aktiva perusahaan. Apabila rasio yang diukur memiliki tingkat yang tinggi maka uang yang dipinjamkan dalam investasi akan semakin semakin bertambah.

DAR $=\frac{\text { Total utang }}{\text { Total aktiva }} \times 100 \%$

2. Debt to Equity Ratio (DER)

Rasio DER diperlukan utuk melihat sejauh mana keterkaitan dalam mengukur sejauh mana kemampuan suatu perusahaan dalam memenuhi dan melaksanakan kewajibannya untuk membayarkan hutang dengan jaminan modal sendiri.

Rasio DER $=\frac{\text { Total utang }}{\text { Total } \text { k kutas }} \times 100 \%$

\section{Pengaruh Struktur Modal yang Diukur dengan $D A R$ dan $R O E$ terhadap Efektivitas Kinerja Keuangan}

Menghitung seberapa besarnya hutang terhadap jumlah aktiva dapat menggunakan Debt to Asset Ratio (DAR) dengan cara melakukan perbandingan antara jumlah hutang perusahaan dengan jumlah aktiva yang telah dipersenkan. Nugraha (2013) dan John (2013) menyebutkan hasil penelitian keduanya memperoleh hasil yang sama yaitu menunjukkan adanya pengaruh yang positif dan signifikan terhadap kinerja keuangan pada perusahaan.

$\mathrm{H}_{1}$ : Debt to Assets Ratio (DAR) diduga berpengaruh terhadap Return on Equity (ROE)

\section{Pengaruh Struktur Modal yang Diukur dengan DER dan ROE terhadap Kinerja Keuangan Perusahaan}

Dalam menetukan perbandingan, peneliti menggunakan DER dengan cara membandingkan antara jumlah hutang yang meliputi hutang lancar dan hutang masa waktu yang lama, sehingga perusahaan dapat menjalankan kinerjanya dengan menggunakan modal yang telah tersedia. Rasio DER yang tinggi menunjukkan perusahaan dapat beroperasi dengan hutang sebagai modalnya. Tingkat pencapaian ROE diperoleh dari tinggi rendahnya DER. Suatu pinjaman 
dapat menghasilkan suatu keuntungan yang efisien, apabila modal yang dikeluarkan lebih sedikit dibandingkan biaya yang diperoleh dari pinjaman, demikian juga sebaliknya.

Penelitian yang dilakukan oleh Nugraha (2013) menunjukkan adanya hubungan yang positif dan berpengaruh signifikan terhadap kinerja keuangan perusahaan, sama halnya dengan hasil penelitian yang dilakukan oleh Binangkit (2014).

$\mathrm{H}_{2}$ : Debt to Equity Ratio (DER) diduga berpengaruh terhadap Return on Equity (ROE)

\section{Kerangka Pemikiran}

Penelitian ini menggunakan dua variabel bebas $\mathrm{X}_{1}$ dan $\mathrm{X}_{2}$ dan satu variabel terikat (Y). Kerangka pemikiran dalam penelitian ini dituliskan pada gambar berikut ini:

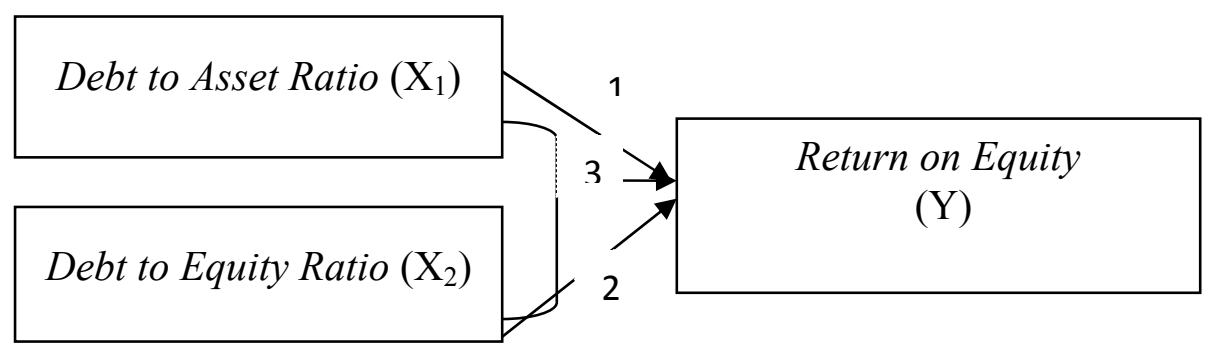

\section{METODE PENELITIAN}

\section{Populasi dan Sampel}

Populasi yang digunakan dalam penelitian ini mengggunakan laporan keuangan tahunan PT. Bank Mandiri. Sampel dalam yang digunakan dalam penelitian ini adalah laporan keuangan tahunan PT. Bank Mandiri selama periode 2013-2017. Dalam pengambilan sampel menggunakan teknik nonprobability sampling. Data yang diambil 8 tahun terakhir (2012-2019) karena fenomena terjadi selama 8 tahun kebelakang, yang terdiri atas laporan neraca, laporan laba rugi, dan arus kasdari kegiatan pendanaan. 


\section{Metode Pengumpulan Data}

Terdapat dua jenis data yang digunakan yaitu data yang bersifat kuantitatif dan kualitatif, data kuantitatif data yang berbentuk bilangan sedangkan data kualitatif berupa laporan tahunan (annual report) selama periode 2012-2019 yang diperoleh dari Bursa Efek Indonesia (BEI) yang diperoleh dari situs www.idx.co.id.

\section{Definisi dan Pengukuran Operasional Variabel}

Pada penelitian ini, berikut adalah operasionalisasi variabel dari penelitian ini:

Tabel 1.2

Operasional Variabel

\begin{tabular}{|c|c|c|c|}
\hline Variabel & Indikator & Deskripsi & Skala \\
\hline $\begin{array}{l}\text { Kinerja } \\
\text { Keuangan } \\
\text { (Y) }\end{array}$ & $\begin{array}{l}\text { Return On } \\
\text { Equity (ROE) }\end{array}$ & $\begin{array}{l}\text { Menunjukan seberapa besar konstribusi } \\
\text { ekuitas dalam menciptakan laba bersih } \\
\text { Alat ukur: } \\
\text { ROE }=\frac{\text { Laba Bersih }}{\text { Total Equitas }}\end{array}$ & $\begin{array}{l}\text { Rasio } \\
\text { Profitabilitas }\end{array}$ \\
\hline $\begin{array}{l}\text { Rasio } \\
\text { struktur } \\
\text { modal (Y) }\end{array}$ & $\begin{array}{l}\text { Debt To } \\
\text { Equty Ratio } \\
(\text { DER) } \\
\\
\text { Debt To } \\
\text { Assets Ratio } \\
\text { (DAR) }\end{array}$ & $\begin{array}{l}\text { Mengukur besarnya proporsi utang } \\
\text { terhadap modal. } \\
\text { Alat ukur: } \\
D E R=\frac{\text { Total Utang }}{\text { Total Modal }} \\
\text { Mengukur perbandingan antara total utang } \\
\text { dan total aset } \\
\text { Alat Ukur: } \\
D A R=\frac{\text { Total Utang }}{\text { Total Aset }}\end{array}$ & $\begin{array}{l}\text { Rasio } \\
\text { Solvabilitas }\end{array}$ \\
\hline
\end{tabular}

\section{Metode Analisis Data}

Alat analisis yang digunakan adalah SPSS 22.0. Analisis statistik menggunakan statistik deskriptif, untuk menganalisa data dengan cara mendeskrifsikan atau menggambarkan data yang telah terkumpul dan statistik inferensial dengan menggunakan analisis regresi linier berganda, uji koefisien determinasi dan uji hipotesis. Adapun persamaan regresi linier brganda adalah :

$$
Y=a+b_{1} x_{1}+b_{2} x_{2}+e
$$

Dimana :

Y : variabel dependent 
$\mathrm{X} 1$ : variabel independent 1

X2 : variabel independent 2

b1 : koefesien regesi variabel antara X1 Dan Y

b2 : Koefesien regresi variabel antara X2 Dan Y

e : eror

\section{HASIL DAN PEMBAHASAN}

\section{Statistik Deskriptif}

Gambaran dari hasil suatu penelitian dengan menggunakan suatu alat analisis Dekriptif :

\section{Rasio Utang Terhadap Aktiva (Debt T o Assets Ratio (DAR))}

Pengukuran seberapa besar jumlah aktiva perusahaan dibiayai dengan utang digunakan rasio $D A R$.

$$
\text { DAR }=\frac{\text { Total utang }}{\text { Total aktiva }} \times 100 \%
$$

Tabel 1.3

Perhitungan Debt T o Assets Ratio (DAR)

PT Bank Mandiri Persero Tbk

\begin{tabular}{|c|c|c|c|}
\hline Tahun & $\begin{array}{c}\text { Total Utang } \\
\text { (Dalam Jutaan) }\end{array}$ & $\begin{array}{c}\text { Total Aktiva } \\
\text { (Dalam Jutaan) }\end{array}$ & DAR \\
\hline 2012 & 407.704 .515 & 449.774 .551 & 90,64 \\
\hline 2013 & 451.379 .750 & 551.891 .704 & 81,78 \\
\hline 2014 & 518.705 .769 & 635.618 .708 & 81,60 \\
\hline 2015 & 596.735 .488 & 733.099 .762 & 81,39 \\
\hline 2016 & 697.019 .624 & 855.039 .673 & 81,51 \\
\hline 2017 & 736.198 .705 & 910.063 .409 & 80,89 \\
\hline 2018 & 824.559 .898 & 1.038 .706 .009 & 79,38 \\
\hline 2019 & 888.026 .817 & 1.124 .700 .847 & 78,95 \\
\hline
\end{tabular}

Sumber: Data Diolah 2021

\section{Rasio Utang Terhadap Modal (Debt T O Equity Ratio (DER))}

Rasio ini digunakan untuk mengukur perimbangan antara kewajiban yang dimiliki perusahaan dengan modal sendiri.

DER $=\frac{\text { Tozal utang }}{\text { Total ekuitas }} \times 100 \%$ 
Tabel 1.4

perhitungan Debt T o Equity Ratio (DER)

Debt T o Equity Ratio (DER) PT Bank Mandiri Persero Tbk

\begin{tabular}{|c|c|c|c|}
\hline Tahun & $\begin{array}{c}\text { Total Utang } \\
\text { (Dalam Jutaan) }\end{array}$ & $\begin{array}{c}\text { Total Ekuitas } \\
\text { (Dalam Jutaan) }\end{array}$ & DER \\
\hline 2012 & 407.704 .515 & 41.542 .808 & 98,14 \\
\hline 2013 & 451.379 .750 & 62.654 .408 & 72,04 \\
\hline 2014 & 518.705 .769 & 76.532 .865 & 67,77 \\
\hline 2015 & 596.735 .488 & 88.790 .596 & 667,20 \\
\hline 2016 & 697.019 .624 & 104.844 .562 & 66,48 \\
\hline 2017 & 736.198 .705 & 119.491 .841 & 61,61 \\
\hline 2018 & 824.559 .898 & 153.369 .723 & 53,76 \\
\hline 2019 & 888.026 .817 & 170.006 .132 & 52,23 \\
\hline
\end{tabular}

Sumber: Data Diolah 2021

\section{Return On Equity (ROE)}

Rasio ini menilai sejauh mana suatu perusahaan mempergunakan sumber daya yang dimiliki untuk mampu memberikan laba atas ekuitas.

$\mathrm{ROE}=\frac{\text { Laba Bersih }}{\text { Ekuinas }} x 100 \%$

Tabel 1.5

Perhitungan Return On Equity (ROE)

PT Bank Mandiri Persero Tbk

\begin{tabular}{|c|c|c|c|}
\hline Tahun & $\begin{array}{c}\text { Laba Bersih } \\
\text { (Dalam Jutaan) }\end{array}$ & $\begin{array}{c}\text { Total Ekuitas } \\
\text { (Dalam Jutaan) }\end{array}$ & ROE \\
\hline 2012 & 9.218 .298 & 41.542 .808 & 22,18 \\
\hline 2013 & 12.695 .885 & 62.654 .408 & 20,26 \\
\hline 2014 & 16.043 .618 & 76.532 .865 & 20,96 \\
\hline 2015 & 18.829 .934 & 88.790 .596 & 21,2 \\
\hline 2016 & 20.654 .783 & 104.844 .562 & 19,70 \\
\hline 2017 & 21.152 .398 & 119.491 .841 & 17,70 \\
\hline 2018 & 14.650 .163 & 153.369 .723 & 9,55 \\
\hline 2019 & 21.443 .042 & 170.006 .132 & 12,61 \\
\hline
\end{tabular}

Sumber: Data Diolah 2021

Tabel 1.6

Analisis Statistik Diskriftif

Descriptive Statistics

\begin{tabular}{|c|c|c|c|c|c|}
\hline & $\mathrm{N}$ & Minimum & Maximum & Mean & Std. Deviation \\
\hline DAR & 8 & 78,95 & 90,64 & 82,0175 & 3,64235 \\
DER & 8 & 52,23 & 98,14 & 67,4038 & 14,22876 \\
ROE & 8 & 9,55 & 22,18 & 18,0200 & 4,55150 \\
Valid N & 8 & & & & \\
(listwise) & & & & & \\
\hline
\end{tabular}

Sumber: Hasil olah data program SPSS 2021

Berdasarkan dari hasil tabel diatas bahwa jumlah data yang valid adalah 8 data. 
1. Nilai terkecil dari Debt to Asset Ratio adalah 78,95 dan nilai maximumnya 90,64 dengan jumlah rata-rata sebesar 82,0175 dan standart deviation/sebaran data adalah 3,64235.

2. Nilai terkecil dari Debt to Equity Ratio adalah 52,23 dan nilai maximumnya 98,14 dengan jumlah rata-rata sebesar 67,4038 dan standart deviation/sebaran data adalah 14,22876.

3. Nilai terkecil dari Return On Equity adalah 9,55 dan nilai maximumnya 22,18 dengan jumlah rata-rata sebesar 18,0200 dan standart deviation/sebaran data adalah 4,55150.

\section{Analisi Statistik Inferensial}

Adapun analisis Inferensial dalam penelitian ini adalah Analisis Regresi Linier Berganda, Uji Koefisien Determinasi $\left(\mathrm{R}^{2}\right)$, Uji Secara Simultan (Uji-F) dan Uji Secara Parsial (Uji-t).

\section{Analisis Regresi Linier Berganda}

Rumus ini di gunakan untuk melihat ada tidaknya pengaruh hubungan anatara variabel independent $\left(\mathrm{X}_{1}\right.$ dan $\left.\mathrm{X}_{2}\right)$ terhadap variabel dependent $(\mathrm{Y})$

Rumus :

$$
Y=a+b_{1} x_{1}+b_{2} x_{2}+e
$$

Tabel 1.7

Hasil Uji Analisis Regresi Linier Berganda

\begin{tabular}{|cc|c|c|c|c|c|}
\hline \multirow{2}{*}{ Model } & \multicolumn{2}{|c|}{$\begin{array}{c}\text { Unstandardized } \\
\text { Coefficients }\end{array}$} & $\begin{array}{c}\text { Standardized } \\
\text { Coefficients }\end{array}$ & \multirow{2}{*}{$\mathrm{T}$} & \multirow{2}{*}{ Sig. } \\
\cline { 3 - 5 } & B & Std. Error & Beta & & \\
\hline \multirow{2}{*}{1} & (Constant) & 186,775 & 69,959 & & 2,670 &, 044 \\
& DAR & $-2,833$ & 1,071 & $-2,267$ & $-2,646$ &, 046 \\
& DER &, 944 &, 274 & 2,952 & 3,444 &, 018 \\
\hline
\end{tabular}

Sumber: Hasil olah data program SPSS, 2021

Berdasarkan hasil analisis data seperti yang telah disajikan pada tabel 1.7 diatas, persamaan regresi yang didapat adalah :

$$
Y=186,775-2,833 X_{1}+0,944 X_{2}
$$

Berarti bila tanpa adanya variabel independent $\left(\mathrm{X}_{1}\right)$ dan independent $\left(\mathrm{X}_{2}\right)$, maka mempunyai keputusan pembelian sebesar 186,775 
1. Nilai koefisien 186,775 menunjukkan dengan adanya $\mathrm{X}_{1}$ dan $\mathrm{X}_{2}$, maka besarnya struktur modal sebesar 186,775

2. Nilai koefisien -2,833, Tanda (-) menunjukkan hubungan Debt To Equity dengan struktur modal adalah negatif, apabila $\mathrm{X}_{1}$ diturunkan sebesar satu satuan sementara $\mathrm{X}_{2}$ memiliki nilai yang konstan, maka struktur modal mengalami penurunan sebesar 2,833

3. Nilai koefisien $+0,944$, Tanda $(+)$ menunjukkan adanya hubungan yang signifikan dan positif antara variabel independent dengan struktur modal, apabila $\mathrm{X}_{2}$ ditingkatkan sebesar satu satuan sementara variabel $\mathrm{X}_{1}$ memiliki nilai yang konstan, maka struktur modal akan mengalami peningkatan sebesar 0,944 .

\section{Uji Koefisien Determinasi $\left(R^{2}\right)$}

Salah satu alat uji yang digunakan yaitu Koefisien determinasi $\left(\mathrm{R}^{2}\right)$, dengan alat uji ini terlihat seberapa besar adanya pengaruh yang berasal dari dalam variabel yang digunakan dan seberapa besar variabel tersebut akan dipengaruhi oleh faktor lain diluar variabel yang diteliti, dengan menerapkan suatu ketentuan dalam pengukuran Nilai $\mathrm{R}^{2}$ terletak antara 0 sampai dengan 1 $\left(0 \leq \mathrm{R}^{2} \leq 1\right)$ memiliki berbagai kriteria dimulai dari hubungan yang sangat kuat sampai hubungan yang lemah (Ghozali (2013). Nilai koefisien determinasi pada penelitian ini adalah bila $\mathrm{R}=0$ berarti diantara pengaruh struktur modal dengan Kinerja Keuangan (Return on Equity) tidak memiliki pengaruh, sedangkan struktur modal dengan Kinerja Keuangan (Return on Equity) menunjukkan R=1 yang berarti terdapat pengaruh.

Tabel 1.8

Uji Koefisien Determinasi $\left(\mathbf{R}^{2}\right)$ Model Summary

\begin{tabular}{|c|c|c|c|c|c|}
\hline Model & R & R Square & $\begin{array}{c}\text { Adjusted R } \\
\text { Square }\end{array}$ & $\begin{array}{c}\text { Std. Error of } \\
\text { the Estimate }\end{array}$ & $\begin{array}{c}\text { Durbin- } \\
\text { Watson }\end{array}$ \\
\hline 1 &, $902^{\mathrm{a}}$ &, 813 &, 738 & 2,32821 & 2,230 \\
\hline
\end{tabular}

a. Predictors: (Constant), DER, DAR

b. Dependent Variable: ROE

Sumber: Hasil olah data program SPSS, 2021

Berdasarkan dari hasil uji diatas bahwa bagian model summary menggaambarkan derajat keeratan hubungan variabel, diperoleh nilai sebesar 
0,902 (a) hal inimemiliki hubungan yang kuat antara kedua variabel independent terhadap variabel dependent. Nilai koefesian determinasi sebesar 0,813 (a) dapat terlihat adanya faktor dalam yang mempengaruhi penelitian sebesar $81,3 \%$ sedangkan sisanya sebesar $18,7 \%$ dipengaruhi oleh faktor luar yang tidak terdapat dalam di dalam penelitian ini.

\section{Uji Simultan (Uji F)}

Pengaruh antara kedua variabel independent yang dilakukan secara serentak terhadap variabel dependent dapat menggunakan suatu alat uji statistik dengan menggunakan uji F.

Tabel 1.9

Uji Simultan (Uji F)

\begin{tabular}{|cc|c|c|c|c|c|}
\hline & Model & Sum of Squares & df & Mean Square & F & Sig. \\
\hline \multirow{4}{*}{1} & Regression & 117,910 & 2 & 58,955 & 10,876 &, $015^{\mathrm{b}}$ \\
& Residual & 27,103 & 5 & 5,421 & & \\
& Total & 145,013 & 7 & & & \\
\hline
\end{tabular}

a. Dependent Variable: ROE

b. Predictors: (Constant), DER, DAR

Sumber: Hasil olah data program SPSS, 2021

Berdasarkan hasil pengolahan data, diperoleh nilai F-hitung sebesar 10,876 dengan taraf signifikan 0,015 , hal ini terlihat bahwa pada pengujian secara serentak antara kedua variabel independent $\left(\mathrm{X}_{1}\right.$ dan $\left.\mathrm{X}_{2}\right)$ terhadap variabel dependent (Y) memiliki pengaruh yang positif dan signifikan.

\section{Uji Parsial (Uji t)}

Selain uji simultan, uji yang digunakan untuk mengetahui ada tidaknya hubungan antara variabel independent $X_{1}$ dan variabel independent $X_{2}$ terhadap variabel dependent (Y) menggunakan uji parsial (uji sendiri-sendiri). Pengujian dilakukan dengan menggunakan significant level 0,05 ( $\alpha=5 \%)$.

Tabel 1.10

Uji Parsial (Uji t)

\begin{tabular}{|c|c|c|c|c|c|}
\hline \multirow[b]{2}{*}{ Model } & \multicolumn{2}{|c|}{$\begin{array}{l}\text { Unstandardized } \\
\text { Coefficients }\end{array}$} & \multirow{2}{*}{$\begin{array}{c}\text { Standardized } \\
\text { Coefficients } \\
\text { Beta }\end{array}$} & \multirow[b]{2}{*}{$\mathrm{T}$} & \multirow[b]{2}{*}{ Sig. } \\
\hline & $\mathrm{B}$ & Std. Error & & & \\
\hline 1 (Constant) & 186,775 & 69,959 & & 2,670 &, 044 \\
\hline DAR & $-2,833$ & 1,071 & $-2,267$ & $-2,646$ & ,046 \\
\hline DER & ,944 & ,274 & 2,952 & 3,444 &, 018 \\
\hline
\end{tabular}

Sumber: Hasil olah data program SPSS, 2021 
Hasil olahan data diperoleh :

(1) Pengujian pengaruh variabel $D A R\left(\mathrm{X}_{1}\right)$ terhadap $R O E$

$\mathrm{H}_{0}: b_{1}=0$ (tidak ada pengaruh antara variabel $D A R$ dan $R O E$ )

$\mathrm{H} 1: b_{2}>0$ (ada pengaruh antara variabel $D A R$ dan $R O E$ )

$\mathrm{df}=\mathrm{n}-\mathrm{k}-1=8-2-1=5$

$\alpha=0,05$

$\mathrm{t}$ hitung $=-2,646$

t tabel $=2,015$

Dengan demikian, maka dapat dikatakan bahwa pengaruh $D A R$ terhadap $R O E$ dengan tingkat kepercayaan 95\% ( $\alpha=0,05)$, diperoleh t hitung $(-2,646)<$

t tabel (2,015), maka $\mathrm{H}_{0}$ diterima dan $\mathrm{H}_{1}$ ditolak, maka secara parsial $D A R$ $\left(\mathrm{X}_{1}\right)$ berpengaruh negatif dan tidak signifikan terhadap $R O E$

(2) Pengujian pengaruh variabel $D E R\left(\mathrm{X}_{2}\right)$ terhadap $R O E$

$\mathrm{H}_{0}: b_{1}=0$ (tidak ada pengaruh antara variabel $D E R$ dan $R O E$ )

$\mathrm{H} 1: b_{2}>0$ (ada pengaruh antara variabel $D E R$ dan $R O E$ )

$\mathrm{df}=\mathrm{n}-\mathrm{k}-1=8-2-1=5$

$\alpha=0,05$

$\mathrm{t}$ hitung $=3,444$

$\mathrm{t}$ tabel $=2,015$

Dengan demikian, maka dapat dikatakan bahwa pengaruh $D E R$ terhadap $R O E$ dengan tingkat kepercayaan 95\% $(\alpha=0,05)$, diperoleh $\mathrm{t}$ hitung $(3,444)>$ t tabel (2,015), maka $\mathrm{H}_{0}$ ditolak dan $\mathrm{H}_{1}$ diterima, maka secara parsial DER $\left(\mathrm{X}_{2}\right)$ berpengaruh positif dan signifikan terhadap $R O E$

\section{KESIMPULAN}

Penelitian ini hanya mengunakan rasio keuangan berupa DAR dan DER untuk menilai struktur modal. Hasil perkembangan kinerja keuangan (Return On Equity) PT Bank Mandiri Tbk tahun 2010-2018 dilihat dari struktur modal (Debt To Asset Ratio dan Debt To Equity) terjadi fluktuasi atau naik turun. Hasil uji F menggambarkan tingkat signifikansi dari Uji Anova atau F-test, di dapat Debt To Asset Ratio dan Debt to Equity Ratio secara bersama-sama (secara simultan) 
berpengaruh terhadap kinerja keuangan (Return On Equity). Sedangkan hasil Uji -t pada variabel independent $X_{1}$ terhadap $Y$ berpengaruh negatif dan tidak signifikan sedangkan variabel independent $\mathrm{X}_{2}$ terhadap $\mathrm{Y}$ berpengaruh positif dan signifikan.

\section{DAFTAR PUSTAKA}

Azizah, Irma Nur. 2016. Pengaruh rasio keuangan terhadap profitabilitas pada industri barang konsumsi di Bursa Efek Indonesia: jurnal bisnis dan manajemen eksekutif vol. 1 no. 1, 2016, artikel 2.

Calvin, Jerry Citra. 2016. Pengaruh Struktur Modal Terhadap Kinerja Keuangan Perusahaan Pada Subsektor Property Dan Real Estate di BEI. Skripsi: Institut Pertanian Bogor.

Dewika, Yunisa Rosa. 2017. Pengaruh struktur modal Terhadap kinerja keuangan pada perusahaan Telekomunikasi Di Bursa Efek Indonesia. Skripsi: Universitas Hasanuddin Makassar.

Fahmi, Irham. 2017. Analisis kinerja keuangan. Alfabeta Bandung.

Hery. 2015. Analisis Laporan Keungan (Pendekatan Rasio Keuangan). CAPS (Center For Academic Publishimg Service).

Mujariyah. 2016. Pengaruh struktur modal terhadap kinerja keuangan (Studi Pada Bank Milik Bumn Yang Terdaftar Di Bursa Efek Indonesia tahun 2008-2014): Universitas Riau.

Rubianti, Nana. 2013. Analisa rasio keuangan untuk menilai kinerja perusahaan pada pt. Admiral lines cabang tanjung pinang: Universitas Maritim Raja Ali Haji 2013.

Wahyuningsih, Evi. 2017. Pengaruh Debt To Equity Ratio (Der) Dan Debt To Asset Ratio (Dar) Terhadap Return On Equity (Roe) Perusahaan Sektor Properti Dan Real Estate Yang Terdaftar Di Bursa Efekindonesia Periode 2014 - 2015. Tugas akhir: Akuntansi Permata Harapan Batam.

Www.Idx.com

Yulsiati, Henny. 2016. pengaruh debt to assets ratio, debt to equity ratiodan net profit margin terhadap return on equity pada perusahaanproperty dan real estate yang terdaftardi bursa efek Indonesia Jurnal Akuntanika, No.2, Vol.1, Januari-Juni2016. 